\title{
Cultivar and Growing Location Effects on Fatty Acids and Minerals in White Lupin Sprouts
}

\author{
Harbans L. Bhardwaj and Anwar A. Hamama \\ Agricultural Research Station, Virginia State University, P.O. Box 9061, Petersburg, VA 23806, USA \\ Correspondence should be addressed to Harbans L. Bhardwaj, hbhardwj@vsu.edu
}

Received 28 August 2012; Accepted 14 September 2012

Academic Editors: G. M. Dal Bello and I. Vasilakoglou

Copyright ( $) 2012$ H. L. Bhardwaj and A. A. Hamama. This is an open access article distributed under the Creative Commons Attribution License, which permits unrestricted use, distribution, and reproduction in any medium, provided the original work is properly cited.

\begin{abstract}
Composition of white lupin (Lupinus albus L.) sprouts was significantly affected by growing location whereas cultivar effects were not significant. In general, sprouts made from seed produced at Petersburg, a location with cooler climate and heavier soils, were superior to those produced from seed produced at Suffolk, a location with warmer climate and sandier soils. White lupin sprouts, on average, contained 41 percent protein and 8 percent oil. Contents of fatty acids, expressed as percentage of oil, were 10, 2, 1, 4, $1,1,43,20,10,5,2,18,82,51$, and 31, respectively, for C16:0, C18:0, C20:0, C22:0, C24:0, C16:1, C18:1, C18:2, C18:3, C20:1, and $\mathrm{C} 22: 1$, total saturated, total unsaturated, monounsaturated, and polyunsaturated fatty acids. The ratio between linoleic (C18:2) and linolenic (C18:3) fatty acids in white lupin sprouts was 0.5 . White lupin sprouts, on average, contained $0.4,0.8,0.3,0.3,0.2$, and 0.04 percent $\mathrm{P}, \mathrm{K}, \mathrm{S}, \mathrm{Ca}, \mathrm{Mg}$, and $\mathrm{Na}$, respectively. White lupin sprouts, on average, contained $51,15,139,10,51, \mathrm{and} 14 \mathrm{mg} \cdot \mathrm{kg}^{-1}$ $\mathrm{Fe}, \mathrm{Al}, \mathrm{Mn}, \mathrm{Cu}, \mathrm{Zn}$, and B, respectively. Based on this study, it was concluded that white lupin sprouts are a potential human food.
\end{abstract}

\section{Introduction}

Sprouts have long been considered a nutritious and healthy food. Historically, the Chinese have consumed sprouts as a healthy food, especially for healing and rejuvenation [1]. In recent years, sprouts have become a popular healthy food in the USA and western meals. Numerous studies have demonstrated that sprouts are one of the most complete and nutritious foods [2-8]. Sprouts have been observed to contribute extensively to the immune system, as excellent detoxificants [9]. Sprouts are considered a predigested food with higher biological efficiency values and lower level of antiphysiologic factors than raw or cooked seeds [3, 10]. Sprouts have been observed to contribute extensively to the immune system, as excellent detoxificants $[5,9]$.

The genus Lupinus consists of over 300 annual species [11] and is a member of the pea (Leguminosae) family. About 100 species of Lupinus occur in the USA and Canada and most are native [12]. White lupin (Lupinus albus L.) is one of four economically important species of this genus (Lupinus albus, L. angustifolius, L. luteus, and L. mutabilis).
Even though reports exist about food uses of Australian lupin (Lupinus angustifolius L.) [13], white lupin (Lupinus albus L.), a cool-season legume plant native to Mediterranean, North Africa, and North and South America, has not been evaluated for production of value-added products such as sprouts. Only one citation indicated that lupin seeds can also be germinated to make a big sprout for vegetable or salad use. Sprouting was shown to reduce alkaloids, phytate, and oligosaccharides in lupin seed [13]. Mature white lupin seeds are considered nutritious and have been used as food for over 3000 years around the Mediterranean and for as much as 6000 years in the Andean highlands. This is especially true since the development of alkaloid-free "sweet" white lupin cultivars by von Sengbusch in 1942 [14].

We have previously reported that growing location significantly affected fresh yield and contents of moisture, crude fiber, oil, and protein, in white lupin sprouts whereas cultivar effects were significant only for fresh yield of sprouts [15] We conducted the current study to characterize effects of growing locations and cultivars on contents of minerals, oil, and fatty acids in white lupin sprouts. 
TABLE 1: Partial analysis of variance (mean squares) for composition of sprouts produced from seed of eight white lupin lines grown at two locations in Virginia during 2003-2004 crop season.

\begin{tabular}{|c|c|c|c|c|c|c|}
\hline Traits & $\mathrm{L}^{\mathrm{x}}$ & $\begin{array}{c}C^{\mathrm{x}} \\
\text { Mean squares }\end{array}$ & $\mathrm{L} * \mathrm{C}$ & $R^{2}$ & $\mathrm{CV}(\%)$ & Mean \\
\hline \multicolumn{7}{|l|}{ Proximates (\%) } \\
\hline Protein (\%) & $65.01^{*}$ & 10.33 & 4.86 & 58 & 7.0 & 41.3 \\
\hline Oil (\%) & $17.23^{* *}$ & 0.72 & 0.29 & 81 & 8.1 & 7.6 \\
\hline \multicolumn{7}{|c|}{ Fatty acids (percentage of oil) } \\
\hline $\mathrm{C} 16: 0$ & $3.01^{*}$ & 0.53 & $1.55^{*}$ & 69 & 7.1 & 10.3 \\
\hline $\mathrm{C} 18: 0$ & $0.20^{*}$ & 0.04 & 0.03 & 67 & 7.4 & 2.1 \\
\hline $\mathrm{C} 20: 0$ & 0.003 & 0.02 & 0.02 & 46 & 11.9 & 1.1 \\
\hline $\mathrm{C} 22: 0$ & $1.77^{*}$ & 0.59 & 0.12 & 57 & 15.4 & 3.8 \\
\hline $\mathrm{C} 24: 0$ & $0.52^{* *}$ & 0.08 & 0.02 & 65 & 30.9 & 0.7 \\
\hline $\mathrm{C} 16: 1$ & $0.04^{* *}$ & $0.01^{*}$ & $0.02^{* *}$ & 84 & 6.5 & 0.9 \\
\hline $\mathrm{C} 18: 1$ & $29.05^{* *}$ & 4.22 & 4.39 & 68 & 4.0 & 42.8 \\
\hline $\mathrm{C} 18: 2$ & 1.91 & 5.10 & 1.22 & 53 & 8.1 & 20.4 \\
\hline $\mathrm{C} 18: 3$ & $9.44^{* *}$ & 1.40 & 1.60 & 67 & 9.6 & 10.4 \\
\hline $\mathrm{C} 20: 1$ & 0.06 & 0.29 & 0.37 & 65 & 8.3 & 5.0 \\
\hline $\mathrm{C} 22: 1$ & 0.22 & 0.13 & 0.18 & 49 & 18.4 & 2.5 \\
\hline SFA & $10.72^{*}$ & 1.71 & 2.71 & 68 & 6.4 & 18.0 \\
\hline UFA & $10.72^{*}$ & 1.71 & 2.71 & 68 & 1.4 & 82.0 \\
\hline MUFA & $24.64^{*}$ & 6.19 & 6.50 & 71 & 3.5 & 51.2 \\
\hline PUFA & 2.86 & 11.0 & 4.33 & 55 & 7.9 & 30.9 \\
\hline Ratio $^{y}$ & $0.04^{* *}$ & 0.001 & 0.003 & 71 & 8.2 & 0.5 \\
\hline \multicolumn{7}{|l|}{ Minerals (\%) } \\
\hline $\mathrm{P}$ & $0.14^{* *}$ & 0.001 & 0.003 & 90 & 8.6 & 0.4 \\
\hline $\mathrm{K}$ & 0.008 & 0.016 & 0.010 & 43 & 15.8 & 0.8 \\
\hline S & $0.026^{* *}$ & 0.000 & 0.000 & 95 & 3.8 & 0.3 \\
\hline $\mathrm{Ca}$ & 0.000 & 0.001 & $0.001^{*}$ & 77 & 5.4 & 0.3 \\
\hline $\mathrm{Mg}$ & 0.000 & 0.000 & $0.000^{*}$ & 74 & 5.9 & 0.2 \\
\hline $\mathrm{Na}$ & 0.000 & 0.000 & 0.000 & 64 & 11.5 & 0.04 \\
\hline \multicolumn{7}{|c|}{ Minerals $\left(\mathrm{mg} \cdot \mathrm{kg}^{-1}\right)$} \\
\hline $\mathrm{Fe}$ & 8.00 & $1018^{* *}$ & 44.4 & 81 & 9.4 & 51.5 \\
\hline $\mathrm{Al}$ & 52.5 & 40.4 & 38.0 & 60 & 33.7 & 15.3 \\
\hline Mn & $262450^{* *}$ & 3862 & 2882 & 85 & 44.3 & 139 \\
\hline $\mathrm{Cu}$ & $24.5^{*}$ & 4.64 & 4.93 & 71 & 17.7 & 9.6 \\
\hline $\mathrm{Zn}$ & $3850^{* *}$ & $63.8^{*}$ & $54.1^{*}$ & 95 & 8.1 & 51.4 \\
\hline $\mathrm{B}$ & $13.8^{* *}$ & $3.64^{*}$ & 1.35 & 73 & 7.7 & 14.3 \\
\hline
\end{tabular}

${ }^{\mathrm{x}} \mathrm{L}$ : location; C: cultivar. Means over two locations and two replications. All contents are based on dry weight basis.

${ }^{y}$ Ratio between content of $\mathrm{C} 18: 2$ and $\mathrm{C} 18: 3$ fatty acids (linoleic: linolenic fatty acids).

$*, * *$ : Significant at $5 \%$ and $1 \%$ levels, respectively.

\section{Materials and Methods}

The lupin seeds, used for sprout making, were produced in field experiments at two locations in Virginia: Petersburg and Suffolk in the 2003-2004 crop growing season. The soil type at Petersburg was an Abel sandy loam with a $\mathrm{pH}$ of 6.2, and the soil at Suffolk was a Raines fine sandy loam with a $\mathrm{pH}$ of 5.6. These field experiments consisted of four replications and were planted on September 27 and September 26, respectively, during 2003 for Petersburg and Suffolk locations and were harvested in summer of 2004. Each plot consisted of four rows spaced $37.5 \mathrm{~cm}$ apart. Each row was $4.5 \mathrm{~m}$ long. The plot size was $6.75 \mathrm{~m}^{2}$. All field experiments received 1 pint per acre of Treflan (Trifluralin) as a preplant incorporated herbicide approximately one week before planting.

Twenty-gram seed from first and second replications were sprouted for 6 days, in a wide mouth jar $(9 \mathrm{~cm} \times 9 \mathrm{~cm} \times$ $16 \mathrm{~cm}$ ) covered with a mesh screen top to insure sufficient air ventilation, under laboratory conditions $\left(22^{\circ} \mathrm{C}\right.$ temperature and $98 \%$ relative humidity and room lighting, 375 lux for $10 \mathrm{~h}$ ). Following initial hydration (seeds were first soaked in room temperature water overnight), seeds were kept moist by rinsing and draining twice a day and the jars inverted 
TABLE 2: Cultivar effects on composition of sprouts produced from seed of eight white lupin lines grown at two locations in Virginia during 2003-2004 crop season.

\begin{tabular}{|c|c|c|c|c|c|c|c|c|}
\hline Traits & L2404 & L2408 & L2411 & L2412 & L2415 & L2417 & L2420 & L2424 \\
\hline \multicolumn{9}{|l|}{ Proximates (\%) } \\
\hline $\operatorname{Protein}(\%)$ & $40.5^{\mathrm{a}}$ & $44.6^{\mathrm{a}}$ & $43.0^{\mathrm{a}}$ & $40.3^{\mathrm{a}}$ & $40.8^{\mathrm{a}}$ & $40.5^{\mathrm{a}}$ & $40.7^{\mathrm{a}}$ & $40.0^{\mathrm{a}}$ \\
\hline Oil (\%) & $8.1^{\mathrm{a}}$ & $7.7^{\mathrm{a}}$ & $7.6^{\mathrm{a}}$ & $7.7^{\mathrm{a}}$ & $8.0^{\mathrm{a}}$ & $6.7^{\mathrm{a}}$ & $7.6^{\mathrm{a}}$ & $7.5^{\mathrm{a}}$ \\
\hline \multicolumn{9}{|c|}{ Fatty acids (percentage of oil) } \\
\hline $\mathrm{C} 16: 0$ & $10.0^{\mathrm{a}}$ & $11.0^{\mathrm{a}}$ & $10.0^{\mathrm{a}}$ & $10.1^{\mathrm{a}}$ & $10.4^{\mathrm{a}}$ & $10.1^{\mathrm{a}}$ & $10.3^{\mathrm{a}}$ & $10.5^{\mathrm{a}}$ \\
\hline $\mathrm{C} 18: 0$ & $1.97^{\mathrm{a}}$ & $1.96^{\mathrm{a}}$ & $2.01^{\mathrm{a}}$ & $2.16^{\mathrm{a}}$ & $2.21^{\mathrm{a}}$ & $2.12^{\mathrm{a}}$ & $2.17^{\mathrm{a}}$ & $2.19^{\mathrm{a}}$ \\
\hline $\mathrm{C} 20: 0$ & $1.00^{\mathrm{a}}$ & $1.04^{\mathrm{a}}$ & $1.12^{\mathrm{a}}$ & $1.17^{\mathrm{a}}$ & $1.16^{\mathrm{a}}$ & $1.14^{\mathrm{a}}$ & $1.18^{\mathrm{a}}$ & $1.09^{\mathrm{a}}$ \\
\hline $\mathrm{C} 22: 0$ & $3.22^{\mathrm{a}}$ & $3.46^{\mathrm{a}}$ & $3.55^{\mathrm{a}}$ & $4.48^{\mathrm{a}}$ & $4.02^{\mathrm{a}}$ & $3.85^{\mathrm{a}}$ & $3.72^{\mathrm{a}}$ & $3.76^{\mathrm{a}}$ \\
\hline $\mathrm{C} 24: 0$ & $0.50^{\mathrm{a}}$ & $0.65^{\mathrm{a}}$ & $0.74^{\mathrm{a}}$ & $0.90^{\mathrm{a}}$ & $0.53^{\mathrm{a}}$ & $0.76^{\mathrm{a}}$ & $0.61^{\mathrm{a}}$ & $0.84^{\mathrm{a}}$ \\
\hline C16: 1 & $0.91^{\mathrm{b}}$ & $1.04^{\mathrm{a}}$ & $0.93^{\mathrm{b}}$ & $0.88^{\mathrm{b}}$ & $0.91^{\mathrm{b}}$ & $0.88^{\mathrm{b}}$ & $0.87^{\mathrm{b}}$ & $0.86^{\mathrm{b}}$ \\
\hline $\mathrm{C} 18: 1$ & $42.4^{\mathrm{a}}$ & $41.3^{\mathrm{a}}$ & $41.8^{\mathrm{a}}$ & $43.0^{\mathrm{a}}$ & $42.7^{\mathrm{a}}$ & $43.6^{\mathrm{a}}$ & $43.2^{\mathrm{a}}$ & $44.6^{\mathrm{a}}$ \\
\hline $\mathrm{C} 18: 2$ & $22.2^{\mathrm{a}}$ & $21.4^{\mathrm{a}}$ & $21.5^{\mathrm{a}}$ & $19.5^{\mathrm{a}}$ & $19.8^{\mathrm{a}}$ & $19.9^{\mathrm{a}}$ & $20.1^{\mathrm{a}}$ & $19.0^{\mathrm{a}}$ \\
\hline $\mathrm{C} 18: 3$ & $11.0^{\mathrm{a}}$ & $11.2^{\mathrm{a}}$ & $10.7^{\mathrm{a}}$ & $10.3^{\mathrm{a}}$ & $10.4^{\mathrm{a}}$ & $10.2^{\mathrm{a}}$ & $10.6^{\mathrm{a}}$ & $9.3^{\mathrm{a}}$ \\
\hline $\mathrm{C} 20: 1$ & $4.62^{\mathrm{a}}$ & $4.60^{\mathrm{a}}$ & $5.09^{\mathrm{a}}$ & $5.11^{\mathrm{a}}$ & $5.36^{\mathrm{a}}$ & $5.01^{\mathrm{a}}$ & $4.83^{\mathrm{a}}$ & $5.17^{\mathrm{a}}$ \\
\hline $\mathrm{C} 22: 1$ & $2.16^{\mathrm{a}}$ & $2.33^{\mathrm{a}}$ & $2.59^{\mathrm{a}}$ & $2.40^{\mathrm{a}}$ & $2.64^{\mathrm{a}}$ & $2.49^{\mathrm{a}}$ & $2.43^{\mathrm{a}}$ & $2.70^{\mathrm{a}}$ \\
\hline SFA & $16.7^{\mathrm{a}}$ & $18.2^{\mathrm{a}}$ & $17.4^{\mathrm{a}}$ & $18.8^{\mathrm{a}}$ & $18.3^{\mathrm{a}}$ & $17.9^{\mathrm{a}}$ & $18.0^{\mathrm{a}}$ & $18.4^{\mathrm{a}}$ \\
\hline UFA & $83.3^{\mathrm{a}}$ & $81.8^{\mathrm{a}}$ & $82.6^{\mathrm{a}}$ & $81.2^{\mathrm{a}}$ & $81.7^{\mathrm{a}}$ & $82.1^{\mathrm{a}}$ & $82.0^{\mathrm{a}}$ & $81.6^{\mathrm{a}}$ \\
\hline MUFA & $50.1^{\mathrm{a}}$ & $49.2^{\mathrm{a}}$ & $50.4^{\mathrm{a}}$ & $51.4^{\mathrm{a}}$ & $51.6^{\mathrm{a}}$ & $51.9^{\mathrm{a}}$ & $51.3^{\mathrm{a}}$ & $53.3^{\mathrm{a}}$ \\
\hline PUFA & $33.2^{\mathrm{a}}$ & $32.6^{\mathrm{a}}$ & $32.1^{\mathrm{a}}$ & $29.8^{\mathrm{a}}$ & $30.1^{\mathrm{a}}$ & $30.1^{\mathrm{a}}$ & $30.7^{\mathrm{a}}$ & $28.3^{\mathrm{a}}$ \\
\hline Ratio $^{y}$ & $0.50^{\mathrm{a}}$ & $0.52^{\mathrm{a}}$ & $0.50^{\mathrm{a}}$ & $0.53^{\mathrm{a}}$ & $0.53^{\mathrm{a}}$ & $0.51^{\mathrm{a}}$ & $0.53^{\mathrm{a}}$ & $0.48^{\mathrm{a}}$ \\
\hline \multicolumn{9}{|l|}{ Minerals (\%) } \\
\hline $\mathrm{P}$ & $0.43^{\mathrm{a}}$ & $0.39^{\mathrm{a}}$ & $0.41^{\mathrm{a}}$ & $0.41^{\mathrm{a}}$ & $0.38^{\mathrm{a}}$ & $0.40^{\mathrm{a}}$ & $0.43^{\mathrm{a}}$ & $0.41^{\mathrm{a}}$ \\
\hline $\mathrm{K}$ & $0.87^{\mathrm{a}}$ & $0.82^{\mathrm{a}}$ & $0.97^{\mathrm{a}}$ & $0.80^{\mathrm{a}}$ & $0.76^{\mathrm{a}}$ & $0.81^{\mathrm{a}}$ & $0.83^{\mathrm{a}}$ & $0.81^{\mathrm{a}}$ \\
\hline S & $0.27^{\mathrm{a}}$ & $0.26^{\mathrm{a}}$ & $0.27^{\mathrm{a}}$ & $0.27^{\mathrm{a}}$ & $0.26^{\mathrm{a}}$ & $0.26^{\mathrm{a}}$ & $0.27^{\mathrm{a}}$ & $0.26^{\mathrm{a}}$ \\
\hline $\mathrm{Ca}$ & $0.31^{\mathrm{a}}$ & $0.29^{\mathrm{a}}$ & $0.29^{\mathrm{a}}$ & $0.31^{\mathrm{a}}$ & $0.31^{\mathrm{a}}$ & $0.30^{\mathrm{a}}$ & $0.33^{\mathrm{a}}$ & $0.30^{\mathrm{a}}$ \\
\hline $\mathrm{Mg}$ & $0.19^{\mathrm{a}}$ & $0.18^{\mathrm{a}}$ & $0.19^{\mathrm{a}}$ & $0.20^{\mathrm{a}}$ & $0.19^{\mathrm{a}}$ & $0.18^{\mathrm{a}}$ & $0.20^{\mathrm{a}}$ & $0.19^{\mathrm{a}}$ \\
\hline $\mathrm{Na}$ & $0.04^{\mathrm{a}}$ & $0.04^{\mathrm{a}}$ & $0.04^{\mathrm{a}}$ & $0.04^{\mathrm{a}}$ & $0.05^{\mathrm{a}}$ & $0.04^{\mathrm{a}}$ & $0.04^{\mathrm{a}}$ & $0.04^{\mathrm{a}}$ \\
\hline \multicolumn{9}{|c|}{ Minerals $\left(\mathrm{mg} \cdot \mathrm{kg}^{-1}\right)$} \\
\hline $\mathrm{Fe}$ & $61.5^{\mathrm{a}}$ & $56.5^{\mathrm{ab}}$ & $57.0^{\mathrm{ab}}$ & $48.5^{\mathrm{c}}$ & $50.0^{\mathrm{ab}}$ & $45.2^{\mathrm{c}}$ & $47.5^{\mathrm{c}}$ & $45.7^{\mathrm{c}}$ \\
\hline $\mathrm{Al}$ & $18.0^{\mathrm{a}}$ & $19.7^{\mathrm{a}}$ & $17.0^{\mathrm{a}}$ & $17.2^{\mathrm{a}}$ & $15.2^{\mathrm{a}}$ & $12.5^{\mathrm{a}}$ & $11.7^{\mathrm{a}}$ & $11.2^{\mathrm{a}}$ \\
\hline $\mathrm{Mn}$ & $11.6^{\mathrm{a}}$ & $17.4^{\mathrm{a}}$ & $18.3^{\mathrm{a}}$ & $12.9^{\mathrm{a}}$ & $10.9^{\mathrm{a}}$ & $11.3^{\mathrm{a}}$ & $16.8^{\mathrm{a}}$ & $11.6^{\mathrm{a}}$ \\
\hline $\mathrm{Cu}$ & $11.0^{\mathrm{a}}$ & $8.7^{\mathrm{a}}$ & $9.5^{\mathrm{a}}$ & $8.2^{\mathrm{a}}$ & $11.0^{\mathrm{a}}$ & $9.2^{\mathrm{a}}$ & $10.5^{\mathrm{a}}$ & $8.7^{\mathrm{a}}$ \\
\hline $\mathrm{Zn}$ & $54^{\mathrm{abc}}$ & $53^{\mathrm{abc}}$ & $56.2^{\mathrm{a}}$ & $49^{\mathrm{bcd}}$ & $52^{\mathrm{abc}}$ & $44.5^{\mathrm{d}}$ & $55^{\mathrm{ab}}$ & $48^{\mathrm{cd}}$ \\
\hline B & $14^{\mathrm{abc}}$ & $15^{\mathrm{ab}}$ & $16^{\mathrm{a}}$ & $14^{\mathrm{bc}}$ & $14^{\mathrm{abc}}$ & $13^{c}$ & $14^{\mathrm{abc}}$ & $13^{c}$ \\
\hline
\end{tabular}

${ }^{\mathrm{x}} \mathrm{L}$ : location; C: cultivar. Means over two locations and two replications. All contents are based on dry weight basis.

y Ratio between content of C18:2 and C18:3 fatty acids (linoleic: linolenic fatty acids).

* Means followed by similar letters are not different according to Duncan's multiple range test at $5 \%$ level of significance.

at a slight angle until the next rinse (from 8 to $10 \mathrm{~h}$ ). At the end of sprouting, the fresh weights were recorded and expressed as fresh yield in $\mathrm{g}$. The sprouts were then dried at $65^{\circ} \mathrm{C}$ until constant weight. Dried sprouts were analyzed by a commercial laboratory (A\&L Agricultural Laboratory, Richmond, VA) according to AOAC standard methods [16] for mineral composition. Protein content was calculated as $\mathrm{N}$ $\times 6.25$. The oil was extracted from two $g$ each of ground dried white lupin sprouts at room temperature by homogenization with hexane/isopropanol $(3: 2, \mathrm{v} / \mathrm{v})$ as described by Hamama et al. [17]. The oil was extracted three times from each sample and bulked to ensure full oil recovery. The oil content was determined gravimetrically after drying under vacuum at $40^{\circ} \mathrm{C}$ and stored under nitrogen at $10^{\circ} \mathrm{C}$ until analysis. The oil content was expressed as $\mathrm{g} \cdot 100^{-1} \mathrm{~g}$ dried sprouts.

All data were analyzed by analysis of variance procedures (PROC GLM) in version 6.11 of SAS [18]. Duncan's multiple range test was used for mean separation with a significance level of $5 \%$.

\section{Results and Discussion}

Locations where seed were produced had more pronounced effects on composition of lupin sprouts as compared to the effects of lupin cultivars (Table 1). Location effects were significant for contents of protein, oil, several fatty acids 
TABLE 3: Location effects on composition of sprouts produced from seed of eight white lupin lines grown at two locations in Virginia during 2003-2004 crop season.

\begin{tabular}{|c|c|c|}
\hline Traits & Petersburg & Suffolk \\
\hline \multicolumn{3}{|l|}{ Proximates $(\%)$} \\
\hline Protein (\%) & $42.7^{\mathrm{a}}$ & $39.9^{\mathrm{b}}$ \\
\hline Oil (\%) & $8.3^{\mathrm{a}}$ & $6.9^{\mathrm{b}}$ \\
\hline \multicolumn{3}{|c|}{ Fatty acids (Percentage of oil) } \\
\hline $\mathrm{C} 16: 0$ & $10.0^{\mathrm{b}}$ & $10.6^{\mathrm{a}}$ \\
\hline $\mathrm{C} 18: 0$ & $2.18^{\mathrm{a}}$ & $2.02^{\mathrm{b}}$ \\
\hline $\mathrm{C} 20: 0$ & $1.12^{\mathrm{a}}$ & $1.10^{\mathrm{a}}$ \\
\hline $\mathrm{C} 22: 0$ & $3.52^{\mathrm{b}}$ & $3.99^{\mathrm{a}}$ \\
\hline $\mathrm{C} 24: 0$ & $0.57^{\mathrm{b}}$ & $0.82^{\mathrm{a}}$ \\
\hline $\mathrm{C} 16: 1$ & $0.87^{\mathrm{b}}$ & $0.95^{\mathrm{a}}$ \\
\hline $\mathrm{C} 18: 1$ & $43.8^{\mathrm{a}}$ & $41.9^{\mathrm{b}}$ \\
\hline $\mathrm{C} 18: 2$ & $20.7^{\mathrm{a}}$ & $20.2^{\mathrm{a}}$ \\
\hline $\mathrm{C} 18: 3$ & $9.9^{\mathrm{b}}$ & $11.0^{\mathrm{a}}$ \\
\hline $\mathrm{C} 20: 1$ & $5.02^{\mathrm{a}}$ & $4.93^{\mathrm{a}}$ \\
\hline $\mathrm{C} 22: 1$ & $2.39^{a}$ & $2.55^{\mathrm{a}}$ \\
\hline SFA & $17.4^{\mathrm{b}}$ & $18.5^{\mathrm{a}}$ \\
\hline UFA & $82.6^{\mathrm{a}}$ & $81.5^{\mathrm{b}}$ \\
\hline MUFA & $52.1^{\mathrm{a}}$ & $50.3^{\mathrm{b}}$ \\
\hline PUFA & $30.6^{\mathrm{a}}$ & $31.2^{\mathrm{a}}$ \\
\hline Ratioy & $0.48^{\mathrm{b}}$ & $0.55^{\mathrm{a}}$ \\
\hline \multicolumn{3}{|l|}{ Minerals (\%) } \\
\hline $\mathrm{P}$ & $0.48^{\mathrm{a}}$ & $0.34^{\mathrm{b}}$ \\
\hline $\mathrm{K}$ & $0.82^{\mathrm{a}}$ & $0.85^{\mathrm{a}}$ \\
\hline S & $0.29^{\mathrm{a}}$ & $0.24^{\mathrm{b}}$ \\
\hline $\mathrm{Ca}$ & $0.31^{\mathrm{a}}$ & $0.30^{\mathrm{a}}$ \\
\hline $\mathrm{Mg}$ & $0.19^{a}$ & $0.19^{\mathrm{a}}$ \\
\hline $\mathrm{Na}$ & $0.04^{\mathrm{a}}$ & $0.04^{\mathrm{a}}$ \\
\hline \multicolumn{3}{|c|}{ Minerals $\left(\mathrm{mg} \cdot \mathrm{kg}^{-1}\right)$} \\
\hline $\mathrm{Fe}$ & $52.0^{\mathrm{a}}$ & $51.0^{\mathrm{a}}$ \\
\hline $\mathrm{Al}$ & $16.6^{\mathrm{a}}$ & $14.1^{\mathrm{a}}$ \\
\hline Mn & $229^{a}$ & $48^{\mathrm{b}}$ \\
\hline $\mathrm{Cu}$ & $10.5^{\mathrm{a}}$ & $8.7^{\mathrm{b}}$ \\
\hline $\mathrm{Zn}$ & $62.4^{\mathrm{a}}$ & $40.4^{\mathrm{b}}$ \\
\hline $\mathrm{B}$ & $15.0^{\mathrm{a}}$ & $13.7^{\mathrm{b}}$ \\
\hline
\end{tabular}

${ }^{\mathrm{x}}$ L: location; C: cultivar. Means over two locations and two replications. All contents are based on dry weight basis.

${ }^{y}$ Ratio between content of C18:2 and C18:3 fatty acids (linoleic : linolenic fatty acids).

* Means followed by similar letters are not different according to Duncan's multiple range test at $5 \%$ level of significance.

(C16:0, C18:0, C22:00, and C24:0) and unsaturated (C16:1, $\mathrm{C} 18: 1$, and $\mathrm{C} 18: 3)$ fatty acids, and several minerals $(\mathrm{B}, \mathrm{Cu}$, $\mathrm{Mn}, \mathrm{P}, \mathrm{S}$, and $\mathrm{Zn}$ ). Location effects (Table 3) were also significant for total saturated, unsaturated, and monounsaturated fatty acids. In addition, locations had significant effects on ratio of C18:2 and C18:3 fatty acids (linoleic and linolenic fatty acids). C18:3 fatty acid is also known as omega-3 fatty acid which is considered important in human nutrition. Cultivar effects on sprout composition were significant only for content of C16:1 fatty acid and three minerals (B, Fe, and
Zn). Growing location and cultivar interaction mean squares were generally nonsignificant indicating that main factor effects (locations and cultivars) can be compared directly.

Highest content of C16:1 was observed in the sprouts made from the seed of L2408 cultivar (1.04 percent) which was greater than that in all other seven cultivars (Table 2). Highest content of $\mathrm{Fe}\left(61.5 \mathrm{mg} \cdot \mathrm{kg}^{-1}\right)$ was observed in sprouts made from seed of L2404 cultivar whereas sprouts made from seed of three other cultivars (L2408, L2411, and L2415) contained statistically similar content of Fe. Significantly lower contents of Fe ( 45.2 to $47.5 \mathrm{mg} \cdot \mathrm{kg}^{-1}$ ) were observed when sprouts were made from the seed of L2417, L2420, and L2424 cultivars. Sprouts made from the seed of L2411 cultivar contained greatest content of $\mathrm{Zn}\left(56.2 \mathrm{mg} \cdot \mathrm{kg}^{-1}\right)$ which was statistically similar to the content in sprouts made from seeds of L2404, L2408, L2415, and L2420 cultivars. Lowest contents of $\mathrm{Zn}$ were observed in sprouts produced from the seed of L2417 and L2424 cultivars. Highest boron content $\left(16 \mathrm{mg} \cdot \mathrm{kg}^{-1}\right)$ was observed in sprouts made from the seed of L2411 cultivar whereas sprouts made from the seed of L2424 cultivar contained lowest content $\left(13 \mathrm{mg} \cdot \mathrm{kg}^{-1}\right)$ of boron. We speculate that limited variation in sprout composition based on varietal differences is due to evaluation of limited number of cultivars. It is hoped that inclusion of a wider number of cultivars in such studies would indicate significant varietal variation in sprout composition.

Sprouts prepared from seed produced at Petersburg location contained significantly higher contents of protein, oil, several fatty acids (C18:0, C18:1, total unsaturated, and mono-unsaturated), and several minerals (B, Cu, Mn, P, S, and $\mathrm{Zn}$ ) whereas sprouts prepared from seed produced at Suffolk location contained significantly higher contents of several fatty acids (C16:0, C22:0, C24:0, C16:1, and total saturated), and ratio between linoleic (C18:2) and linolenic (C18:3) fatty acids. The ratio between linoleic and linolenic fatty acids is becoming important in human nutrition. It has been observed that $1: 1$ to $4: 1$ ratio of $n-6$ and $n-3$ fatty acids is desirable for human health $[19,20]$. Therefore sprouts produced from seed produced at Petersburg were characterized as relatively desirable for human concentration as compared to those produced from seed produced at Suffolk location. Sprouts produced from seed produced at Suffolk location had significantly lower contents of all minerals exhibiting significant differences.

Our studies indicated significant differences in composition of sprouts based on locations where seed were grown. Petersburg location is characterized by sandy loam soils whereas Suffolk location is characterized by sandy soils. Additionally, ambient temperatures at Petersburg location are cooler than those at Suffolk locations. Based on historical data, Petersburg location (average lowest, average highest, and average mean temperatures of 18,72 , and $46^{\circ} \mathrm{F}$, resp.) is cooler than the Suffolk location (average lowest, average highest, and average mean temperatures of 15,79 , and $47^{\circ} \mathrm{F}, \mathrm{resp}$.). We speculate that these differences contribute towards differential composition of white lupin seed which then manifests in composition of lupin sprouts. 
White lupin is being evaluated as an alternative grain and winter legume cover crop in Virginia [21]. Seeds from eight white lupin lines, included in a field trial conducted during 2003-2004 crop season at two locations in Virginia (Petersburg and Suffolk), were used for spouting. Therefore, we conclude that lupin seed produced in cooler climates and loam soils result in production of sprouts containing higher contents of fatty acids and minerals.

Our results indicated that cultivar effects for sprout composition were not significant; however, we are not suggesting that only weather and soil conditions affect lupin seed and sprout composition. Rather, the composition of white lupin seed and sprouts produced from these seed is expected to be determined by agroclimatic and host plant genetic factors.

\section{Conclusion}

This study demonstrates that seed growing location has a significant effect on quality of sprouts, a location with cooler climate and heavier soil being desirable. Additionally, use of white lupin seeds to produce nutritious sprouts for human consumption has been indicated to be a viable option. Use of lupin sprouts has the potential to provide a new and alternative source of sprouts, thus providing additional sources of sprouts for human consumption.

\section{Acknowledgments}

Funding support from U.S. Department of Agriculture, National Institute of Food and Agriculture, 1890 Institutions Capacity Building Grant Program is greatly appreciated. Contribution of Virginia State University, Agricultural Research Station, Journal Article Series Number 296 is also acknowledged. The use of any trade names or vendors does not imply approval to the exclusion of other products or vendors that may also be suitable.

\section{References}

[1] S. Azulay, "Sprouts-the forgotten food (part 1). An overview of sprouts and nutrition," in San Diego Earth Times (SDET) Health and Diet, pp. 1-5, San Diego, Calif, USA, 1997.

[2] K. Lorenz, "Cereal sprouts: composition, nutritive value, food applications," Critical Reviews in Food Science and Nutrition, vol. 13, no. 4, pp. 353-385, 1980.

[3] T. Y. Chung, E. N. Nwokolo, and J. S. Sim, "Compositional and digestibility changes in sprouted barley and canola seeds," Plant Foods for Human Nutrition, vol. 39, no. 3, pp. 267-278, 1989.

[4] H. M. Bau, C. Villaume, J. P. Nicolas, and L. Méjean, "Effect of germination on chemical composition, biochemical constituents and antinutritional factors of soya bean (Glycine max) seeds," Journal of the Science of Food and Agriculture, vol. 73, no. 1, pp. 1-9, 1997.

[5] F. Yang, T. K. Basu, and B. Ooraikul, "Studies on germination conditions and antioxidant contents of wheat grain," International Journal of Food Sciences and Nutrition, vol. 52, no. 4, pp. 319-330, 2001.
[6] M. Kaur and B. L. Kawatra, "Effect of domestic processing on zinc bioavailability from ricebean (Vigna umbellata) diets," Plant Foods for Human Nutrition, vol. 57, no. 3-4, pp. 307-318, 2002.

[7] H. L. Bhardwaj and A. A. Hamama, "Yield and nutritional quality of canola sprouts," HortScience, vol. 42, no. 7, pp. 1656-1658, 2007.

[8] D. Zielinska, J. Frias, M. K. Piskuła, H. Kozłowska, H. Zielinski, and C. Vidal-Valverde, "Evaluation of the antioxidant capacity of lupin sprouts germinated in the presence of selenium," European Food Research and Technology, vol. 227, no. 6, pp. 1711-1720, 2008.

[9] N. Andarwulan, D. Fardiaz, G. A. Wattimena, and K. Shetty, "Antioxidant activity associated with lipid and phenolic mobilization during seed germination of Pangium edule Reinw," Journal of Agricultural and Food Chemistry, vol. 47, no. 8, pp. 3158-3163, 1999.

[10] R. Balasaraswathi and S. Sadasivam, "Changes in oil, sugars and nitrogenous components during germination of sunflower seeds, Helianthus annuus," Plant Foods for Human Nutrition, vol. 51, no. 1, pp. 71-77, 1997.

[11] W. Hondelmann, "The lupin-ancient and modern crop plant," Theoretical and Applied Genetics, vol. 68, no. 1-2, pp. $1-9,1984$.

[12] J. M. Kingsbury, Poisonous Plants of the United States and Canada, Prentice-Hall, Englewood Cliffs, NJ, USA, 1964.

[13] S. G. Dagnia, D. S. Petterson, R. R. Bell, and F. V. Flanagan, "Germination alters the nutritional value of lupin seed," Journal of the Science of Food and Agriculture, vol. 60, pp. 419423, 1992.

[14] W. A. Cowling, C. Hughie, and W. Swiecicki, "Lupin breeding," in Lupins as Crop Plants: Biology, Production and Utilization, J. S. Gladstones, C. A. Atkins, and J. Hamblin, Eds., CAB International, Wallingford, UK, 1998.

[15] H. L. Bhardwaj and A. A. Hamama, "Yield and nutritional quality traits of white lupin sprouts," Journal of Agricultural Science, vol. 4, no. 1, pp. 58-61, 2012.

[16] AOAC, Official Methods of Analysis. Association of Official Analytical Chemists, Arlington, Va, USA, 16th edition, 1995.

[17] A. A. Hamama, H. L. Bhardwaj, and D. E. Starner, "Genotype and growing location effects on phytosterols in canola oil," Journal of the American Oil Chemists' Society, vol. 80, no. 11, pp. 1121-1126, 2003.

[18] SAS, SAS System for Windows, SAS Institute, Cary, NC, USA, 2002.

[19] M. A. Schmidt, Brain-Building Nutrition, The Healing Power of Fats and Oils, North Atlantic Books, Berkeley, Calif, USA, 2nd edition, 2001.

[20] C. Watkins, "Fundamental fats," International News on Fats, Oils and Related Materials, vol. 15, no. 10, pp. 638-640, 2004.

[21] H. L. Bhardwaj, A. A. Hamama, and E. van Santen, "White lupin performance and nutritional value as affected by planting date and row spacing," Agronomy Journal, vol. 96, no. 2, pp. 580-583, 2004. 


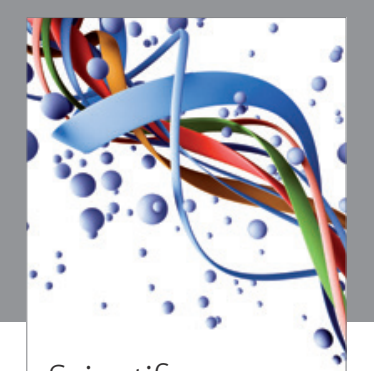

Scientifica
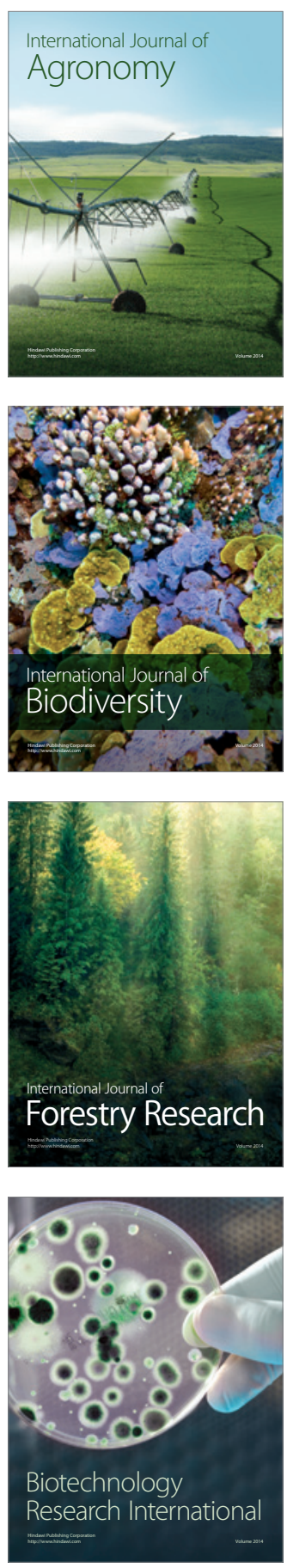
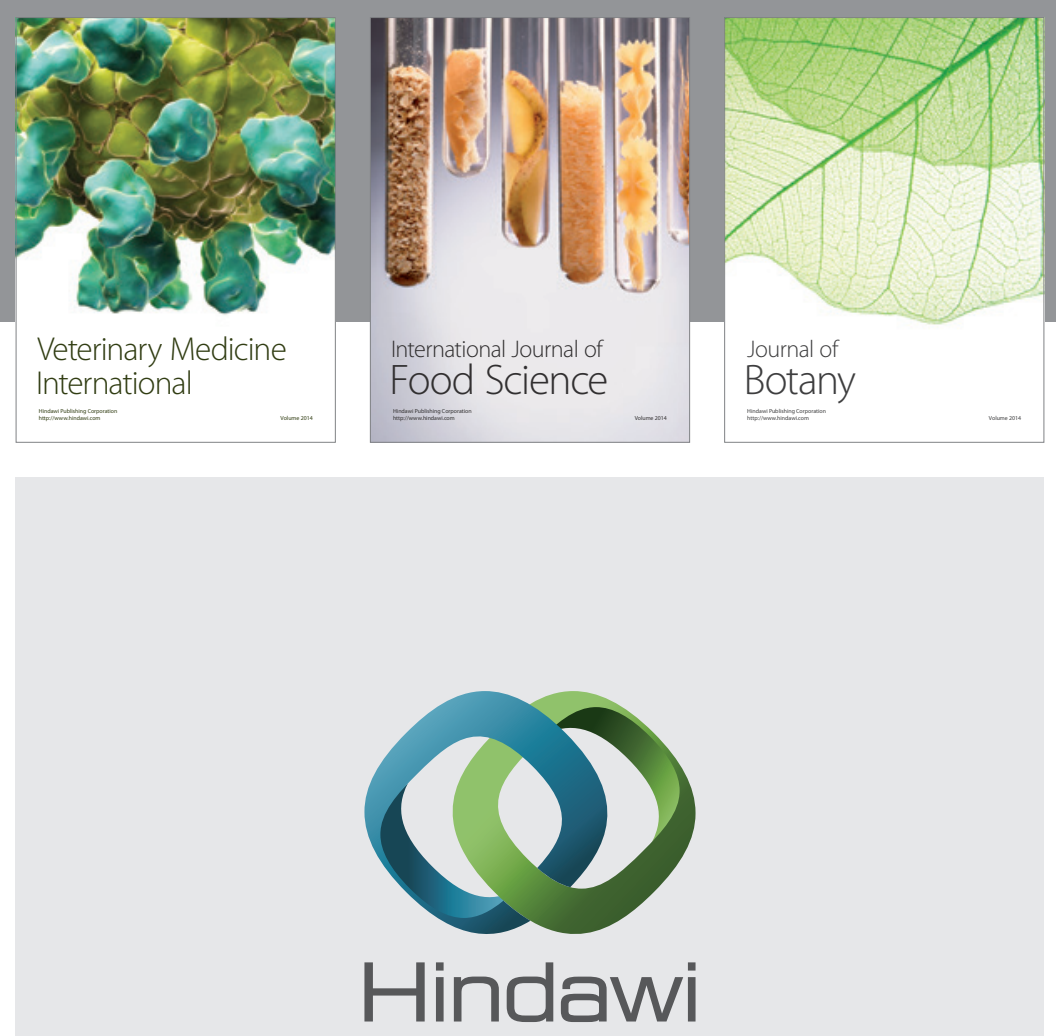

Submit your manuscripts at

http://www.hindawi.com
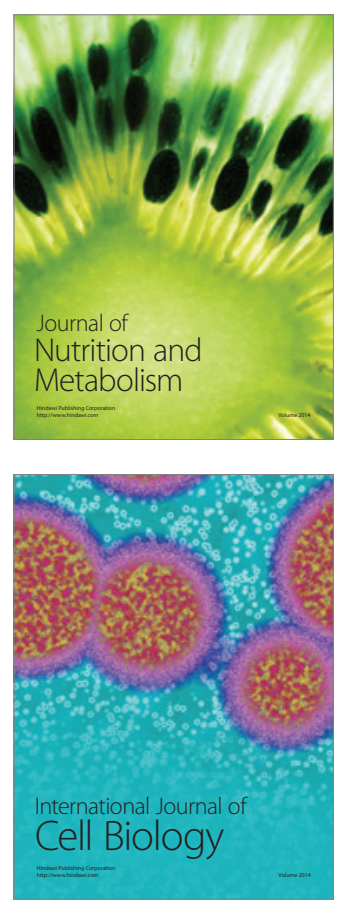
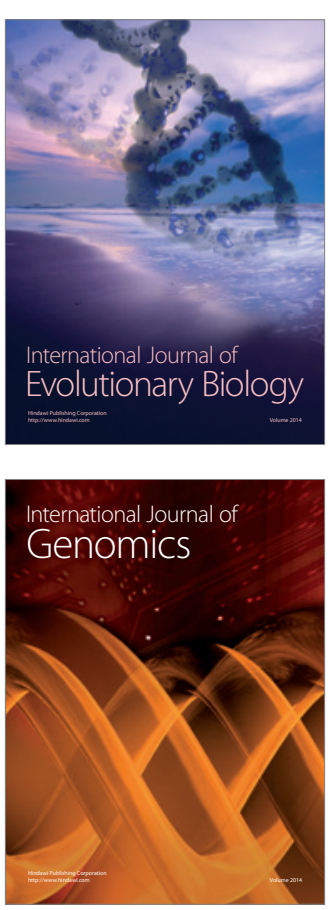
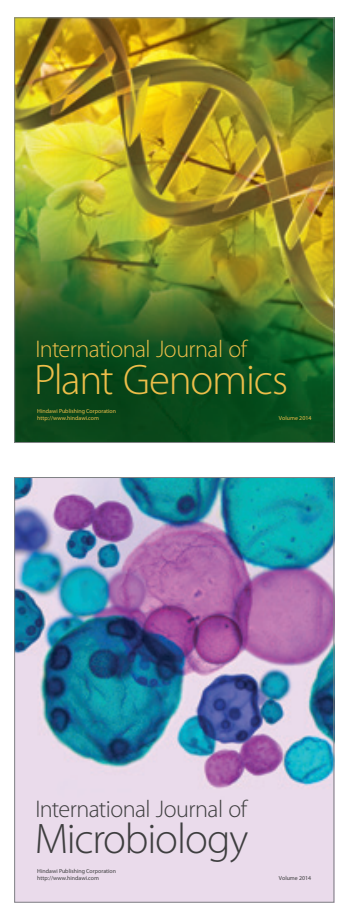

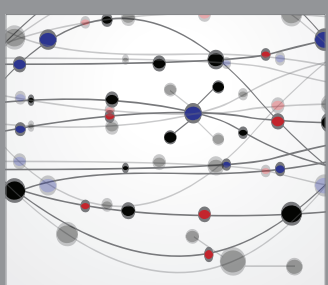

The Scientific World Journal
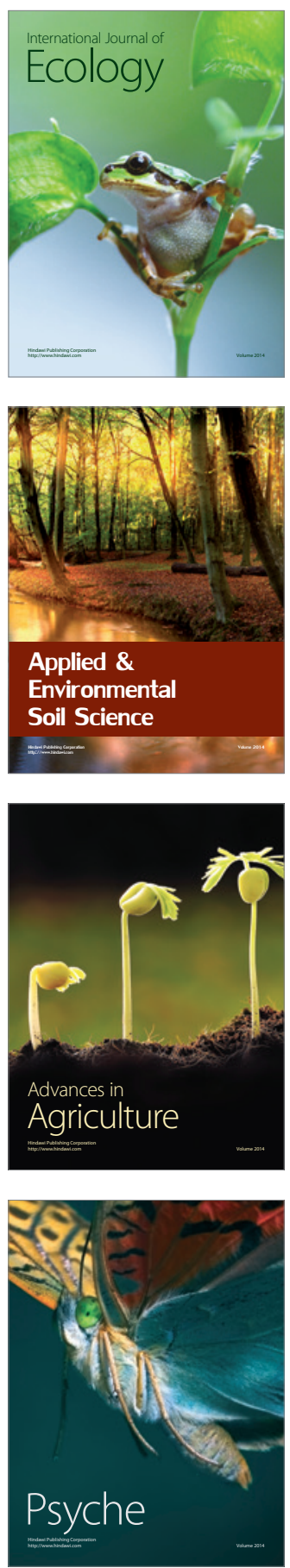